\title{
Carbonic Anhydrase I Deficiency
}

National Cancer Institute

\section{Source}

National Cancer Institute. Carbonic Anhydrase I Deficiency. NCI Thesaurus. Code C132290.

Decreased or absent activity of the enzyme carbonic anhydrase 1, due to loss-offunction mutation(s) in the gene CA1. 